\title{
MANAGEMENT MOTIVATION IN THE COMPANIES IN KAZAKHSTAN
}

\section{Talgat Uteubayev ${ }^{1}$}

\begin{abstract}
A range of socio-economic factors affects the motivation of a company's labor force. Many of these represent independent subsystems of the company's overarching approach. They involve various economic and social indicators, but not all are implemented or included in personnel management. Without a dedicated system in place, it is almost impossible to create labor motivation within an enterprise. This research examines personnel services within several oil and gas companies in the Republic of Kazakhstan. These somewhat overlook the socio-economic factors of the region, while developing labor motivation in the framework of the Company Strategy. The paper shows that companies need personnel services to carry out labor relations. This is valuable for equal economic relations between employees and employers, an effective labor market, and the wider management of social problems affecting productivity.
\end{abstract}

UDC Classification: 338.24, DOI: http://dx.doi.org/10.12955/cbup.v3.596

Keywords: Motivation, Human Resources Management, Oil and Gas Companies, Kazakhstan

\section{Introduction}

With the emergence of the economic market in Kazakhstan, the enhancement of staff performance in the oil and gas companies needs special attention. To examine this on a scientific basis requires many years of domestic and international experience. The issue concerning personnel is most importance at present with the economic development of a large number of countries in the world (Adams, \& Hicks, 2000; Algiev, 2012; Atkinson, 1964).

The research examines personnel services within several oil and gas companies in the Republic of Kazakhstan (RK). The author shows that companies need personnel services to reform labor relations. This is not only to compensate employees, but also to establish equal economic relations between employees and employers, an effective labor market, and the wider management of social issues affecting productivity. Companies in this process control the running of personnel services of national enterprises and production. These services must improve production and staff quality, initiate the interest of employees in organizational discipline, and expedite introducing of innovations in sections of productivity. This will help normalize the functioning of production and technical services, and other branches, creating conditions for a stable and dynamic growth in production in each particular branch of the national economy (Kurmanov, 2013; Labour Code of the Republic of Kazakhstan, 2007).

\section{The system of personnel management}

This study compared oil and gas companies in RK in terms of their system of managerial and economic methods for personnel management (Table 1) (Kurmanov et al. 2013).

The analysis of the existing managerial and economic system in these companies show that only the Limited Liability Partnership "Tengizchevroil” practices a wide range of different managerial and economic methods for personnel management, including motivational incentives for effective labor.

The rest of the companies impose strict requirements for workers to comply with organizational matters. However, these weakly handle the system of premiums, wages rises, and bonuses to stimulate productivity and work quality (Kurmanov et al. 2013).

Furthermore, the studies show that the company "Agip KCO”, which leads the construction of the refinery, "Bolashak", on the "Batis-Esken" deposit, violates the constitutional rights of Kazakh

1 Talgat Uteubayev, $\mathrm{PhD}$ student, Information Systems Management Institute (ISMA), Latvia, talgat4001@mail.ru 
workers. These laborers work 60 hours instead of the normal 40 hours a week, without adequate security and safety practices (Kurmanov et al. 2013).

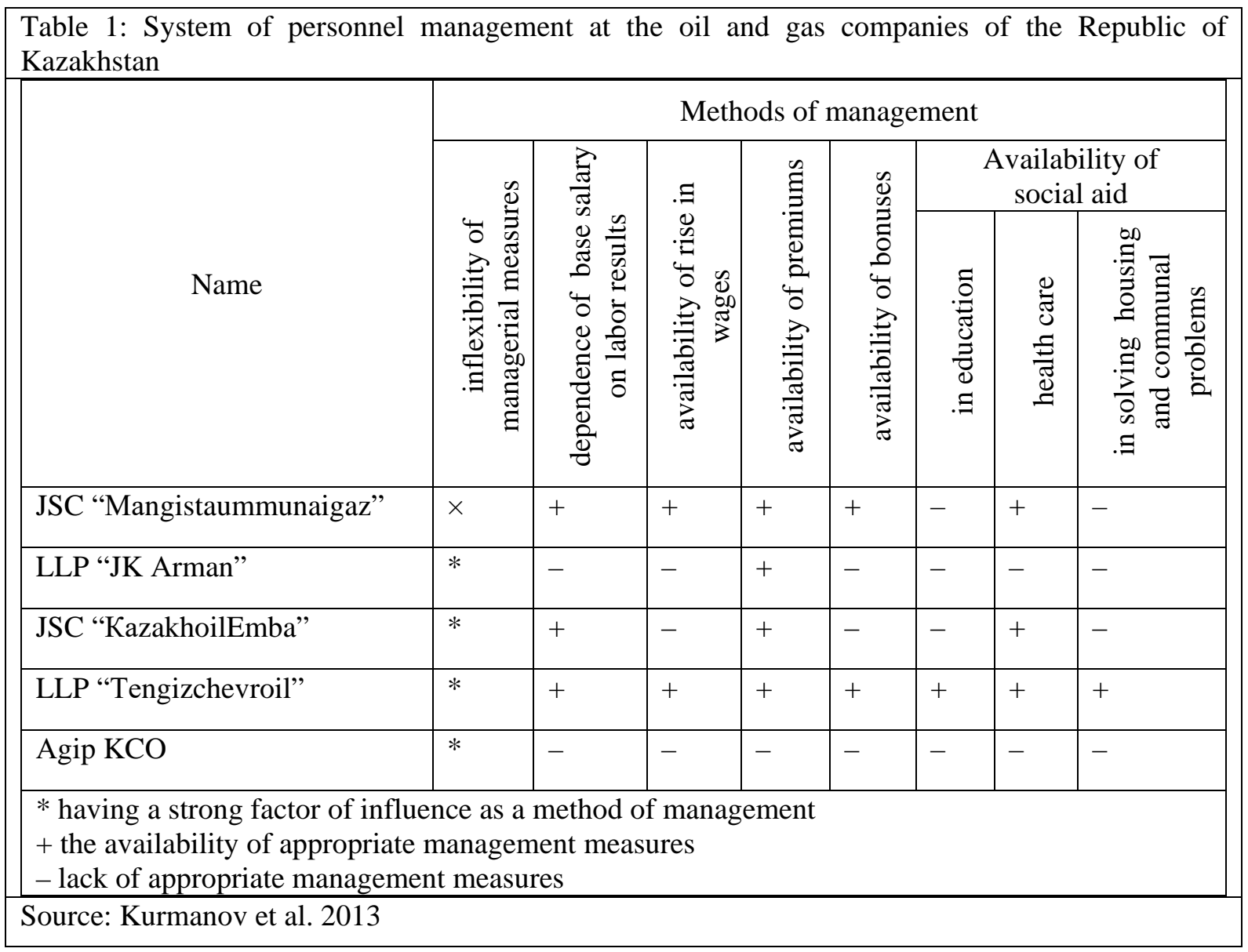

All companies, except LLP “Tengizchevroil”, failed to assist employees with professional training. Additionally, they had no mechanisms for preserving staff revenue, e.g. incentives to stimulate motivation to improve performance.

\section{Motivational model for labor remuneration in oil and gas companies}

The main motivational model for labor remuneration in Kazakh oil and gas companies involved a multistage approach (Figure 1).

Figure 1 shows the basis of remuneration with the basic rate of executable functions, realized within a particular profession or occupation. Professional job training, level of education, and work experience may increase remuneration for a worker. Additional payments, such as regular premiums or one-time award bonuses may apply according to special working condition. In addition, the framework of specific conditions may include social control methods, as defined in collective bargaining agreements or high-level management decisions. However, as it is evident from Table 1, many oil and gas companies in the RK fail to adequately apply the social approaches to management. This exemplifies a typical situation for all Kazakhstan enterprises (Kurmanov et al. 2013).

Such an economic motivation determines the effectiveness of economic stimulus. While many oil and gas companies in Kazakhstan pay bonuses and allowances, fewer implement the social package, and seldom beyond the requirements stipulated in the legislation of the RK. Additionally, in the oil and gas regions of Kazakhstan, observations indicate the local population is in dire economic and social need. At the same time, the high wages of the oil and gas industry employees have little effect on improving 
the situation, but rather promote the growth of market prices. The companies' employees anger the local population, and this sometimes causes conflict. These issues demand governmental assessment of the oil and gas companies' potential to engage in helping solve the social problems of company employees and the problems of the region where their companies operate (Kurmanov et al. 2013).

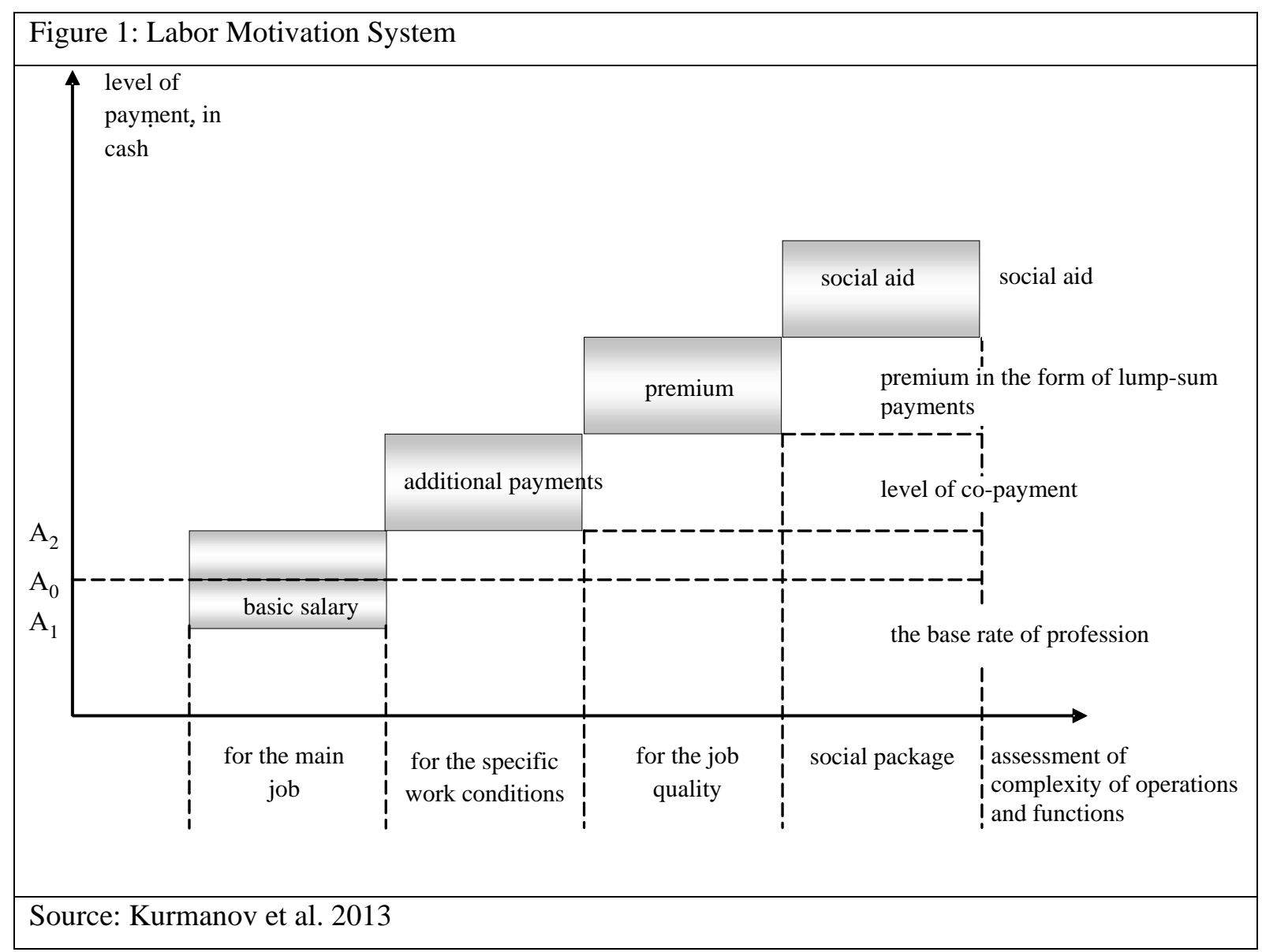

In addition, the RK ratified the international treaties, which apply directly to labor relations, except in the cases when an international treaty requires issuing of a special law for its application.

Based on the Article 9 in "The Labor Code of the RK" the working process of the oil and gas companies related to the following relationships:

- labor relations;

- directly related to labor relations;

- social partnership; and

- relations on security and labor protection (Labour Code of the Republic of Kazakhstan, 2007).

Therefore, Kazakhstan oil and gas companies work with their own staff in the framework of "The Labor Code of the RK". Other normative legal acts, which regulate labor activity in the country and provide guarantees to the citizens of Kazakhstan, according to Article 145 in "The Labor Code of the RK", involve the following:

- protection against all forms of discrimination and ensuring equal access to get profession and work;

- training, retraining, professional development and organization of social works for the unemployed;

- promoting the development of small business and entrepreneurship; 
- organization of labor intermediation through the authorized body on employment in the private employment agency;

- providing vocational orientation information about free job places and vacancies;

- orientation of the system of vocational education for training specialists which are in demand of the labor market;

- inter-regional redistribution of the labor force in accordance with the governmental programs;

- development and implementation of measures to identify and legalize the labor relations;

- investment contracts to ascertain the responsibility for investors to arrange trainings, creation of new and preservation of existing job places;

- creation of conditions to develop vocational training, retraining, and advanced training directly in the organization;

- interaction of the authorized bodies on employment issues with employers; and

- ensuring the conditions for the employment of persons belonging to the target groups (Kurmanov et al. 2013, Labour Code of the Republic of Kazakhstan, 2007).

\section{The analysis of the system of the personnel services in the oil and gas companies}

Interviews of the personnel in certain Kazakhstan companies, including JSC "Anaco," "Karachaganak Petroleum," and LLP "Ah-danmunay", showed they see no difference between the functions of personnel departments and human resource management departments. Moreover, some line managers of small companies and service stations engaged in oil mining fail to understand why they need a specialized personnel department. They believe that $2-3$ company employees suffice for filling in documents (Kurmanov et al. 2013).

As a result, in Kazakhstan, a new pattern has appeared with the labor results of employees in no way related to the companies' activity. Almost everywhere, the employees disengage in the management of productivity. They receive no information about the financial results of the operation of their businesses. The oil and gas companies of Kazakhstan display an authoritarian style of management that becomes stronger and stronger, and the object of paying wage increases and premiums is not always clear (Kurmanov et al. 2013).

Furthermore, the respondents pointed out that the social assistance of the company is usually a small one-off cost, not comparable to the revenues of the companies in terms of their production and marketing activities. The result clearly revealed a low level of transference of authority from one level of management to another. It also showed that the budget allocated for this purpose was insufficient, and that the personnel services are not at capacity. However, those oil companies with foreign participation have many of these problems solved (Kurmanov et al. 2013).

The condition of the equipment and technologies in the oil companies of Kazakhstan, especially the small ones, is concerning. There is a high level of equipment wear and a low level of automation in the oil production and transportation, which aggravate the negative tendencies (Willis-Shattuck, et al., 2008; Yermekov, \& Kuatbekov, 2013).

There are problems with the level of total wages paid for the actual amount of work performed. This includes bonuses in companies, the lack of clear regulations on labor tariffing, and the impact of cost of living rises on the growth of wages (Kurmanov et al. 2013).

Possible instruments to overcome these negative tendencies in Kazakhstan include the following:

- establish additional criteria to reduce payments, effect dismissal of an employee, or increase 
salaries according to specific indicators;

- $\quad$ widely develop social labor incentives and social programs within companies;

- develop the parallel movement of employees between positions with the help of an organized system of alignment and replacement of professions;

- create an ideal system of employee's labor assessment with the help of an expert (quality); and

- develop a ranking system of quality indicators as the basis for additional material incentives for each worker.

Implementing the latter requires legal determination of the status of the employee within the company. Apart from the description of the workplace, job descriptions, and access to rules relating to bonuses, the following need consideration:

- standards to perform work functions;

- possible ways to enlarge empowerments;

- perspectives to change specific forms of activity; and

- standards of professional development and opportunities of the employee while receiving additional training or experience (Madina, 2008; Baltabaeva, Ibraev, \& DeLellis, 2011; Algiev, 2012).

These issues provide an opportunity to create the relevant SWOT-analyses relevant to personnel services in Kazakhstan oil companies (Table 2), similar to enterprises in other branches of industry and relevant foreign companies.

Table 2 shows that the presence of threats and opportunities. Ways to improve the effectiveness of personnel management in Kazakhstan oil companies mainly occur in the area of expanding power and authority of personnel services. However, this closely links to one of the most pressing issues for the country as a whole. This is the creation of a modern infrastructure for training and retraining of human resource potential in the country with the help of effective mechanisms for implementing innovative technologies (Kurmanov et al. 2013).

In addition, currently for the large oil and gas companies in Kazakhstan, the problem of employees' removal from participating in production management is obvious. The same problem occurs in all large Kazakh management structures. It is likely a consequence of reform in the country when the authoritarian style of management dominated all levels of management. Consequently, company processes lack the necessary mechanisms to involve employees in production management and develop their potential, and hence, democratize control systems (Adams \& Hicks, 2000; Omarkhan, 2012; Zamanbekov, 2013).

As a result, Kazakhstan has weakly developed methods to stimulate management and cannot provide a strong influence to motivate workers and improve their desire to maximize efficiency. In this respect, the most positive examples are from Germany, which has excellent conditions to involve employees into management. This occurred through acquiring shares in companies from Norway, Sweden, Denmark, France, and Japan, where many elements of certain participation have already been developed (Kurmanov et al. 2013).

There are many worthy examples in the USA, where companies actively involve, not only their employees, but also the population of the country, through shares to participate in the managerial process in the enterprise. Kazakhstan is following, in some sense, similar mistakes to Russia with emphasis placed on the population participating in the corporatization of enterprises, but comparatively small support for participation of foreign investors (Kurmanov et al. 2013). 


\begin{tabular}{|c|c|}
\hline Weakness & Strength \\
\hline $\begin{array}{l}\text { - } \text { poor arrangement of personnel planning; } \\
\text { - insufficient participation of personnel } \\
\text { services in motivating activity of } \\
\text { personnel; } \\
\text { - insufficient participation of personnel } \\
\text { services in staff training, retraining and } \\
\text { forming of labor potential; } \\
\text { - small range of functions; } \\
\text { - insufficient participation in the enterprise } \\
\text { management; } \\
\text { - the absence of links between the personnel } \\
\text { development plans and enterprise } \\
\text { developing; } \\
\text { - absence of plans to adapt to the } \\
\text { possibilities of market changes; and } \\
\text { - weak linkage with educational institutions } \\
\text { that educate necessary. }\end{array}$ & $\begin{array}{l}\text { - There are certain social programs that are } \\
\text { attractive for the personnel; } \\
\text { - There is a better economic motivation than } \\
\text { in other branches of industry; } \\
\text { - There are certain methods of selecting and } \\
\text { testing of staff; } \\
\text { - Efficient organization of works in the } \\
\text { framework of company's tasks; } \\
\text { - There are some elements of managerial } \\
\text { culture; } \\
\text { - There are training programs in some of the } \\
\text { oil and gas corporations; and } \\
\text { - Gradual creation of feedback links with } \\
\text { educational institutions. }\end{array}$ \\
\hline Threats & Opportunities \\
\hline $\begin{array}{l}\text { - Possibilities to replace staff with younger } \\
\text { specialists; } \\
\text { - Tendencies to enlarge export potential of } \\
\text { foreign specialists; } \\
\text { - Growth of perspectives to lose the national } \\
\text { labor potential; } \\
\text { - Reduction of influence on effectiveness of } \\
\text { using labor resources; } \\
\text { - Lack of growth in possibilities to improve } \\
\text { the effectiveness of resource potential } \\
\text { usage in the future; } \\
\text { - Lack of employees with links to the } \\
\text { development of productive capital because } \\
\text { of their exclusion from the property; } \\
\text { - Absence of employees participating in } \\
\text { production management of the company; } \\
\text { and } \\
\text { - Not fully, effective or organized } \\
\text { management structures. }\end{array}$ & $\begin{array}{l}\text { - Promote young people to master } \\
\text { professions of the oil and gas complex ; } \\
\text { - Enlargement of functions of the personnel } \\
\text { services concerning rights and } \\
\text { responsibilities, credentials and power; } \\
\text { - Creation of the conditions for participation } \\
\text { in the process of optimal managerial } \\
\text { decision making on the planned basis; } \\
\text { - Forming of plan-orders to train young } \\
\text { specialists; } \\
\text { - Creation of the ranking system of the labor } \\
\text { utilization quality assessment for economic } \\
\text { and social motivation; } \\
\text { - Impact development on the specialists } \\
\text { training in the country and forming national } \\
\text { security of the state; } \\
\text { - Creation of more developed system of } \\
\text { social labor stimulus, which can influence } \\
\text { on the patriotic attitude of the employees } \\
\text { towards their own companies; } \\
\text { - Developing of co organized management } \\
\text { structures. }\end{array}$ \\
\hline
\end{tabular}

Source: Kurmanov et al. 2013 
At the All-Russia Personnel Congress in 2003, more than 40 per cent of questioned respondents did not understand the purpose of personnel services in company processes. This lack of understanding underlies a system where managers and shareholders become richer from improving production functioning, but the basic worker receives little additional income. Moreover, the worker expresses no initiative to develop the many working processes. They also receive no additional income from growth of production income. They are digressing gradually to middle and low profitable levels of population, and human resource managers have limited power and insufficient budget allocated to work with the personnel.

All this fails to enhance the enterprise relating to the higher level of human resource management, and leaves personnel services with limited possibilities to work with the personnel.

\section{Conclusion}

1. The oil and gas companies, as the highest production enterprises of Kazakhstan, are the most developed businesses concerning efficient personnel management for motivational incentives to improve productivity. Searching for ways to improve staff management in the oil and gas companies is strategic for all production enterprises of Kazakhstan.

2. Many modern economists point out the falsehood of having a choice of objectives for maximizing the growth of revenue in the market place. The priorities should be preserving and developing the labor resources. This fact requires new approaches to human resource management in Kazakhstan.

3. The rational formation of management structures takes a special place within personnel management. However, while searching for methods to form these structures, certain principles need to apply, while the systemization of these would allow improvements in management of Kazakhstan enterprises.

4. Kazakhstan's step system for economic stimulus, which relates to the quality and intensity of working activity, is poorly implemented. Almost everywhere, companies fail to administer the social approaches to manage and support the economic ones, and thus strengthen the motivation of the system as a whole. Creating such a system demands preliminary planning and assessment, because many incentives depend on the organizational budgets. This should not take for granted the direction of high-level managers, and needs to consider improving the planning of work at Kazakhstan enterprises.

\section{References}

Adams, O., \& Hicks, V. (2000). Pay and non-pay incentives, performance and motivation. Human Resources Development Journal, 4(3), 1-25. Retrieved from http://www.who.int/hrh/en/HRDJ_4_3_02.pdf.

Algiev, S. (2012). Statistical analysis of knowledge sharing practices in international Oil and Gas Company in Kazakhstan. Ekonomika i statistika: ežekvartal'nyj naučno-informacionnyj žurnal, 3, 14-17.

Atkinson, J. W. (1964). An introduction to motivation. Princeton, New Jersey: Van Nostrand.

Baltabaeva, S., Ibraev, S., \& DeLellis, N. (2011). Modern approaches to management through motivation. EurAsian Journal of BioMedicine, 4(3), 1-15. Retreived from http://biomedj.com/2011_N3/01_Baltabaeva_Modern_approaches1.pdf.

Kurmanov, N., Kabdullina, G., Karbetova, Z., Tuzubekova, M., Doshan, A., \& Karbetova, S. (2013). Motivation of employees' labor activity in oil and gas companies in Kazakhstan. World Applied Sciences Journal 26 (12), 1556-1561.

Labour Code of the Republic of Kazakhstan (2007). Retrieved from http://www.wipo.int/wipolex/en/details.jsp?id=11515 \# 251.

Madina, Z. (2008). Determinants of Foreign Direct Investment in Emerging Market Economy: Evidence from Kazakhstan Oil Market. (Master's Thesis). Available from the National Library of Thesis and Dissertations in Taiwan. http://handle.ncl.edu.tw/11296/ndltd/02620899422149749523. 
Omarkhan, D. N. (2012). Motivation of work as an element of managerial process by the bank personnel. Proceedings ARSA (Proceedings in ARSA - Advanced Research in Scientific Areas), 1(1), 128-130.

Willis-Shattuck, M., Bidwell, P., Thomas, S., Wyness, L., Blaauw, D., \& Ditlopo, P. (2008). Motivation and retention of health workers in developing countries: a systematic review. BMC Health Services Research, 8(247). doi: 10.1186/14726963-8-247. Retrieved from http://www.biomedcentral.com/1472-6963/8/247

Yermekov, M., \& Kuatbekov, Z. (2013). Leadership Qualities as a Factor in the Motivation Mechanism of Mid-Level Civil Servants Career Development (By the Example of the Republic of Kazakhstan). Middle-East Journal of Scientific Research, 16(3), 362-367.

Zamanbekov, S. Z. (2013). Diversification of the economy of Kazakhstan as condition of engineering development on innovative basis. World Applied Sciences Journal, 25(5), 747-750. 